\title{
CONSANGUINEOUS MARRIAGES AMONG IRANIAN MANDAEANS LIVING IN SOUTH-WEST IRAN
}

\author{
MOSTAFA SAADAT ${ }^{1}$ AND MAHDIS ZARGHAMI \\ Department of Biology, College of Sciences, Shiraz University, Iran
}

\begin{abstract}
Summary. Several studies have indicated that consanguineous marriages (unions between biologically related persons) are associated with increased risk of autosomal recessive diseases and several multifactorial traits. Mandaeans are a closed ethno-religious community living in areas of southern Iraq and Iran (Khuzestan Province). There are currently no data on the prevalence of consanguineous marriages among Mandaeans. The present study was carried out in 2016 to determine the prevalence of consanguinity among Iranian Mandaeans living in Khuzestan Province, south-west Iran. A total of 137 couples (urban areas: 79 couples; rural areas: 58 couples) were included in the study. Information on the consanguineous marriages of the subjects was collected through direct interviews. Marriages were classified by the degree of relationship between couples as double first cousins, first cousins, first cousin once removed, second cousins and unrelated marriages. The coefficient of inbreeding $(F)$ was calculated for each couple and the mean coefficient of inbreeding $(\alpha)$ estimated for the population, stratified by rural and urban areas. The overall frequency of consanguinity was found to be $50.7 \%$ in urban and $86.2 \%$ in rural areas. There was a significant difference between rural and urban areas in types of marriages $\left(\chi^{2}=24.8, \mathrm{df}=4, p<0.001\right)$ and first cousin marriages $(51.8 \%)$ were the most common type. The overall $\alpha$-value was estimated to be 0.0363 for the Iranian Mandaean population.
\end{abstract}

\section{Introduction}

A consanguineous marriage is defined as a union between biologically related persons. This type of marriage is common in many Asian and African populations (Saha \& El Sheikh, 1988; Tuncbilek \& Koc, 1994; Bittles, 2001; Alper et al., 2004; COSIT, 2006; Othman \& Saadat, 2009; Shawky et al., 2011; El-Kheshen \& Saadat, 2013). Iranian populations show high levels of consanguineous marriages (Saadat et al., 2004; Rafiee \& Saadat, 2011). Consanguinity is a long-standing social habit (Bittles, 2001; Saadat, 2007, 2008 b) and its frequency is associated with several demographic, religious, cultural and

${ }^{1}$ Corresponding author. Email: saadat@shirazu.ac.ir 
socioeconomic factors (Bittles, 2001; Hamamy et al., 2005; Akrami \& Osati, 2007; Saadat, 2007).

Considering that consanguinity results in homozygosity in offspring, it is associated with an elevation in the risk of autosomal recessive disease and several multifactorial complex traits (Bittles \& Neel, 1994; Stoltenberg et al., 1999; Bittles, 2001; Saadat \& Zendeh-Boodi, 2006; Saadat, 2008a; Tadmouri et al., 2009; Mansour et al., 2010; Saadat \& Vakili-Ghartavol, 2010; Nafissi et al., 2010, 2011; Anvar et al., 2011; Saadat, 2011, 2015a).

Previous studies have shown that Iranian people are a heterogeneous population (Amirshahi et al., 1992; Rafiee et al., 2010; Fallahzadeh-Abarghooei et al., 2015; Saadat, 2015b). The Mandaean community is one of the Iranian sub-populations. Mandaeans are a closed ethno-religious community, practising Mandaeism, which is a Gnostic religion (Aramaic manda means 'knowledge', as does the Greek gnosis). Mandaeism has a strongly dualistic worldview. The connection with the Quranic Sabians provided them with acknowledgment as People of the Book - a legal minority religion within the Muslim community. According to most scholars, Mandaeans migrated from Jordan/Palestine areas to southern Iraq and south-west Iran areas about 2000 years ago. They are Semites and speak a dialect of Eastern Aramaic known as Mandaic. Aramaic is a language family belonging to the Semitic subfamily of the Afroasiatic language family (Buckley, 2002).

The patterns of consanguinity among several Iranian populations have been reported previously (Saadat et al., 2004; Rafiee \& Saadat, 2011). To the authors' knowledge, there are no data for prevalence of consanguineous marriages among Iranian and Iraqis Mandaeans. Therefore, the present study was carried out in Khuzestan Province.

\section{Methods}

\section{Subjects}

This cross-sectional study was carried out in Khuzestan Province in south-west Iran in 2016. A total of 137 Mandaean couples (urban areas: 79 couples; rural areas: 58 couples) were included in the study. No other ethnic/religious groups were included. Data on consanguineous marriages were collected using a simple questionnaire by interview. The questionnaires were completed by a trained interviewer. The work has been carried out in accordance with the Code of Ethics of the World Medical Association (Declaration of Helsinki) for studies in humans. Informed consent was obtained from all participants.

\section{Consanguineous marriages}

The coefficient of inbreeding $(F)$ is the probability that an individual has received both alleles of a pair from an identical ancestral allele. Marriages were classified by the degree of biological relationship between couples as double first cousins $(F=1 / 8)$, first cousins $(F=1 / 16)$, first cousin once removed $(F=1 / 32)$, second cousins $(F=1 / 64)$ and unrelated marriages $(F=0)$. The average coefficient of inbreeding $(\alpha)$ was calculated as $F=\sum P_{i} F_{i}$, where $P_{i}$ and $F_{i}$ are the frequency and coefficient of inbreeding of each mating type, respectively.

First cousins may be the children of two brothers (patrilateral parallel cousins), two sisters (matrilateral parallel cousins) or a brother and a sister (cross-cousins). 


\section{Statistical analysis}

The chi-squared test $\left(\chi^{2}\right)$ was used to compare mating pattern frequencies between study groups. Statistical analysis was performed using the statistical software package SPSS (SPSS Inc., Chicago, IL, USA; Version 11.5). A probability of $p<0.05$ was considered statistically significant.

\section{Results and Discussion}

Table 1 shows the frequency of the various types of marriages in urban and rural areas. The data showed that the overall frequency of consanguinity was $50.7 \%$ in urban and $86.2 \%$ in rural areas. The equivalent mean inbreeding coefficient $(\alpha)$ was 0.0272 and 0.0487 in urban and rural areas, respectively. There was a significant difference between rural and urban areas for the types of marriages $\left(\chi^{2}=24.8, \mathrm{df}=4, p<0.001\right)$. This means that consanguinity was higher in rural areas compared with urban areas. A similar finding has been reported by other investigators in Algeria (Benallegue \& Kedji, 1984), Jordan (Khoury \& Massad, 1992), Iraq (COSIT, 2006), Turkey (Alper et al., 2004), Egypt (Hafez et al., 1983), Syria (Othman \& Saadat, 2009) and Afghanistan (Saify \& Saadat, 2012; Saadat \& Tajbakhsh, 2013).

First cousin marriages $(51.8 \%)$ were the most common type of marriages and the $\alpha$-value was estimated to be 0.0363 for the Iranian Mandaean population. The rates of first cousin marriages were $35.4 \%$ and $74.1 \%$ in urban and rural areas, respectively.

It should be noted that among several west Asian countries, the most common form of consanguineous marriage is between first cousins (Hafez et al., 1983; Tuncbilek \& Koc, 1994; Alper et al., 2004; Hamamy et al., 2005; Othman \& Saadat, 2009; Rafiee \& Saadat, 2011; El-Kheshen \& Saadat, 2013). Among Iranian populations, first cousin marriages account for about $28 \%$ of all marriages (Saadat et al., 2004), which is similar to the findings of other reports from Arabic countries (Hafez et al., 1983; Benallegue \& Kedji, 1984; Khoury \& Massad, 1992; Othman \& Saadat, 2009; Shawky et al., 2011; El-Kheshen \& Saadat, 2013). The present finding might be at least in part interpreted by the fact that Mandaeans originated in the west of Asia (Buckley, 2002), and that consanguinity was deeply rooted in the populations living in these areas (Bittles, 2001; Saadat, 2007, 2008b).

Table 1. Frequency distribution of different types of consanguineous marriages in Iranian Mandaeans, Khuzestan Province, 2016

\begin{tabular}{lccc}
\hline Type of marriage & $\begin{array}{c}\text { Urban areas } \\
n(\%)\end{array}$ & $\begin{array}{c}\text { Rural areas } \\
n(\%)\end{array}$ & $\begin{array}{c}\text { Total } \\
n(\%)\end{array}$ \\
\hline First cousins & $28(35.4)$ & $43(74.1)$ & $71(51.8)$ \\
Double first cousins & $1(1.3)$ & $0(0)$ & $1(0.7)$ \\
First cousins once removed & $7(8.9)$ & $2(3.4)$ & $9(6.6)$ \\
Second cousins & $4(5.1)$ & $5(8.6)$ & $9(6.6)$ \\
Unrelated & $39(49.3)$ & $8(13.8)$ & $47(34.3)$ \\
Total & 79 & 58 & 137 \\
\hline
\end{tabular}


Patrilateral parallel cousin marriages were the most common type of consanguineous marriages among Mandaeans (data not shown). It should be noted that it is a similar story in Iran (Saadat et al., 2004), Syria (Othman \& Saadat, 2009), Lebanon (El-Kheshen \& Saadat, 2013) and several other populations in Asia (Saify \& Saadat, 2012; Saadat \& Tajbakhsh, 2013).

The prevalence of consanguinity among the Arab population living in Iran has previously been reported to be $49.0 \%$ (Saadat et al., 2004). Although Mandaeans and Arabs are Semites, there a significant difference was found between these populations regarding consanguineous marriages $\left(\chi^{2}=303.3\right.$, $\left.\mathrm{df}=4, p<0.001\right)$. Mandaeans showed a higher level of consanguinity compared with Iranian Arabs mainly living in Khuzestan Province. This point confirms that consanguineous marriages are a very important factor in maintaining social stability (Tadmouri et al., 2009). Therefore, it might be concluded that, at least in part, Mandaeans selected a high level of consanguineous marriages to keep their ethno-religious community.

On the other hand, it has been shown that attitude and subsequently practice towards consanguineous marriages is strongly correlated with the historical background of populations (Saadat, 2007, 2008b). Iranian Mandaeans originated from the west of Asia (Buckley, 2002), where at the present time consanguinity is high in these populations. It seems that a high level of marriages with relatives was a feature of west Asian populations.

It should be mentioned that the small sample size was a major limitation of this study. The study demonstrated a very high level of consanguineous marriage among Iranian Mandaeans. It has been shown that consanguinity significantly increases the prevalence of inherited autosomal recessive diseases and many multifactorial traits such as infertility, congenital disorders, and mental retardation (Bittles et al., 1993; Bittles \& Neel, 1994; Stoltenberg et al., 1999; Bittles, 2001; Saadat \& Zendeh-Boodi, 2006; Saadat, 2008a; Tadmouri et al., 2009; Mansour et al., 2010; Saadat \& Vakili-Ghartavol, 2010; Nafissi et al., 2010, 2011; Anvar et al., 2011; Saadat, 2011, 2015a). The harmful consequences of consanguineous mating emphasize the need for genetic counselling in the Mandaean community and the importance of preventive action to raise awareness about the risks of consanguinity.

\section{Acknowledgments}

The authors are indebted to the study participants for their close co-operation. They also thank Mr Salam Choheili (Great Leader of the Iranian Mandaean) for his support. They are also grateful to Dr Maryam Ansari-Lari for her contribution in revising and editing the manuscript. The study was supported by Shiraz University, Iran (94GRD1M1741). The authors have no conflicts of interest to declare.

\section{References}

Akrami, S. M \& Osati, Z. (2007) Is consanguineous marriage religiously encouraged? Islamic and Iranian considerations. Journal of Biosocial Science 39, 313-316.

Alper, O. M., Erengin, H., Manguoglu, A. E., Bilgen, T., Cetin, Z., Dedeoglu, N. \& Luleci, G. (2004) Consanguineous marriages in the province of Antalya, Turkey. Annales de génétique 47, $129-138$. 
Amirshahi, P., Sunderland, E., Farhud, D. D., Tavakoli, S. H., Daneshmand, P. \& Papiha, S. S. (1992) Population genetics of the peoples of Iran I. Genetic polymorphisms of blood groups, serum proteins and red cell enzymes. International Journal of Anthropology 7, 1-10.

Anvar, Z., Namavar-Jahromi, B. \& Saadat, M. (2011) Association between consanguineous marriages and risk of pre-eclampsia. Archives of Gynecology and Obstetrics 283(Supplement 1), $5-7$.

Benallegue, A. \& Kedji, F. (1984) Consanguinité et santé publique: étude algérienne. Archives Francaises de Pediatrie 41, 435-440.

Bittles, A. H. (2001) Consanguinity and its relevance to clinical genetics. Clinical Genetics 60, 89-98.

Bittles, A. H., Grant, J. C. \& Shami, S. A. (1993) An evaluation of consanguinity as a determinant of reproductive behaviour and mortality in Pakistan. International Journal of Epidemiology 22, 463-467.

Bittles, A. H. \& Neel, J. V. (1994) The costs of human inbreeding and their implications for variations at the DNA level. Nature Genetics 8, 117-121.

Buckley, J. J. (2002) The Mandaeans: Ancient Texts and Modern People. First edition. Oxford University Press, New York.

COSIT (2006) Iraq Living Conditions Survey 2004: Vol. II: Analytical Report. Central Organization for Statistics and Information Technology (COSIT), Ministry of Planning and Development Cooperation, Baghdad.

El-Kheshen, G. \& Saadat, M. (2013) Prevalence of consanguineous marriages among Shi'a populations of Lebanon. Journal of Biosocial Science 45, 675-682.

Fallahzadeh-Abarghooei, L., Zahedi, T., Mirabedi, F. \& Saadat, M. (2015) Allelic prevalence of intron 3 insertion/deletion genetic polymorphism of DNA double-strand break repair gene $X R C C 4$ in four healthy Iranian populations. Egyptian Journal of Medical Human Genetics 16, 215-218.

Hafez, M., El-Tahan, H., Awadalla, M., El-Khayat, H., Abdel-Gafar, A. \& Ghoneim, M. (1983) Consanguineous matings in the Egyptian population. Journal of Medical Genetics 20, 58-60.

Hamamy, H., Jamhawi, L., Al-Darawsheh, J. \& Ajlouni, K. (2005) Consanguineous marriages in Jordan: why is the rate changing with time? Clinical Genetics 67, 511-516.

Khoury, S.A. \& Massad, D. (1992) Consanguineous marriage in Jordan. American Journal of Medical Genetics 43, 769-775.

Mansour, H., Fathi, W., Klei, L., Wood, J., Chowdari, K., Watson, A. et al. (2010) Consanguinity and increased risk for schizophrenia in Egypt. Schizophrenia Research 120, 108-112.

Nafissi, S., Ansari-Lari, M. \& Saadat, M. (2010) Effect of inbreeding on weight gain of offspring from birth to 12 months after birth, a study from Iran. Journal of Biosocial Science 42, 195-200.

Nafissi, S., Ansari-Lari, M. \& Saadat, M. (2011) Parental consanguineous marriages and age at onset of schizophrenia. Schizophrenia Research 126, 298-299.

Othman, H. \& Saadat, M. (2009) Prevalence of consanguineous marriages in Syria. Journal of Biosocial Science 41, 685-692.

Rafiee, L. \& Saadat, M. (2011) Prevalence of consanguineous marriages among Iranian Georgians. Journal of Biosocial Science 43, 47-50.

Rafiee, L., Saadat, I. \& Saadat, M. (2010) Glutathione S-transferase genetic polymorphisms (GSTM1, GSTT1 and GSTO2) in three Iranian populations. Molecular Biology Reports 37, $155-158$.

Saadat, M. (2007) Consanguinity marriages in Iranian folktales. Community Genetics 10, 38-40.

Saadat, M. (2008a) Consanguinity and national IQ. Journal of Epidemiology and Community Health 62, 566-567.

Saadat, M. (2008b) Is consanguineous marriage historically encouraged? Journal of Biosocial Science 40, 153-154. 
Saadat, M. (2011) Association between healthy life expectancy at birth and consanguineous marriages in 63 countries. Journal of Biosocial Science 43, 475-480.

Saadat, M. (2015a) Age-standardized incidence rates for leukemia associated with consanguineous marriages in 68 countries, an ecological study. Mediterranean Journal of Hematology and Infectious Diseases 7, e2015027.

Saadat, M. (2015b) Distribution of $A C E$ insertion/deletion (I/D) polymorphism in Iranian populations. Molecular Biology Research Communications 4, 63-66.

Saadat, M., Ansari-Lari, M. \& Farhud, D. D. (2004) Consanguineous marriage in Iran. Annals of Human Biology 31, 263-269.

Saadat, M. \& Tajbakhsh, K. (2013) Prevalence of consanguineous marriages in west and south of Afghanistan. Journal of Biosocial Science 45, 799-805.

Saadat, M. \& Vakili-Ghartavol, R. (2010) Parental consanguinity and susceptibility to drug abuse among offspring, a case-control study. Psychiatry Research 180, 57-59.

Saadat, M. \& Zendeh-Boodi, Z. (2006) Correlation between incidences of self-inflicted burns and means of inbreeding coefficients, an ecological study. Annals of Epidemiology 16, 708-711.

Saha, N. \& El Sheikh, F. S. (1988) Inbreeding levels in Khartoum. Journal of Biosocial Science 20, 333-336.

Saify, K. \& Saadat, M. (2012) Consanguineous marriages in Afghanistan. Journal of Biosocial Science 44, 73-81.

Shawky, R. M., El-Awady, M. Y., Elsayedm, S. M. \& Hamadanm, G. E. (2011) Consanguineous matings among Egyptian population. Egyptian Journal of Medical Human Genetics 12, 157-163.

Stoltenberg, C., Magnus, P., Skrondal, A. \& Lie, R. T. (1999) Consanguinity and recurrence risk of stillbirth and infant death. American Journal of Public Health 89, 517-523.

Tadmouri, G. O., Nair, P., Obeid, T., Al Ali, M. T., Al Khaja, N. \& Hamamy, H. A. (2009) Consanguinity and reproductive health among Arabs. Reproductive Health 6, 17.

Tuncbilek, E. \& Koc, I. (1994) Consanguineous marriage in Turkey and its impact on fertility and mortality. Annual Human Genetics 58, 321-329. 